\title{
Muhammadiyah dan NU: Penjaga Moderatisme Islam di Indonesia
}

\author{
Zakiya Darajat \\ Universitas Islam Negeri Jakarta \\ zakiyadarajat99@gmail.com
}

Diterima: 2-9-2016, direvisi: 8-1-2017, disetujui: 25-1-2017

\begin{abstract}
Islam has been expressed through its adherents in many ways. Sometimes the expression has been judged as hard and even arrogant. This is not the case with Islam in Indonesia which has been shown more friendly expression of Islam. However, the radical movements have challenged this peaceful image of Islam in Indonesian. The research which mainly utilized the library sources has concludes that Islam in Indonesia is still considered to be a moderate Islam and in this case, Muhammadiyah and Nahdlatul Ulama are two organizations which can be seen as the guardians of Islamic moderatism in Indonesia.
\end{abstract}

Keywords: Moderatism, Islam in Indonesia, Muhammadiyah, Nahdlatul Ulama

\begin{abstract}
Abstrak
Wajah Islam di berbagai belahan dunia kadang terlihat keras dan bahkan arogant. Hal ini berbeda dengan Islam di Indonesia yang cenderung ramah. Namun demikian, gambaran Islam yang ramah ini sempat terganggu dengan adanya gerakan radikal. Penelitian studi pustaka ini menunjukkan bahwa Islam di Indonesia masih tetap dapat dinilai sebagai Islam yang moderat, dalam hal ini, Muhammadiyah dan Nahdlatul Ulama adalah dua organisasi yang menjadi penjaga moderatisme Islam di Indonesia
\end{abstract}

Kata Kunci: Moderatisme, Islam Indonesia, Muhammadiyah, Nahdlatul Ulama

\section{Pendahuluan}

Islam adalah agama rahmat yang diturunkan di antaranya untuk mengajarkan perilaku yang santun. Namun demikian, cintra Islam sebagai agama yang penuh rahmat kadang tercoreng dengan adanya gerakan atau gelompok yang mengatasnamakan Islam, namun kemudian berperilaku menyimpang atau tidak sejalan dengan ajaran Islam. Kelompok-kelompok teroris yang mengatasnamakan agama sebagai justifikasi gerakan mereka adalah contoh nyata tantangan ini.

Di Indonesia, tantangan ini berupaya diredam oleh dua organisasi Muslim terbesar, yakni, Muhammadiyah dan Nahdlatul Ulama. Tulisan ini berupaya menyajikan kembali bahasan tentang moderatisme agama dan bagaimana contohnya diaplikasikan oleh dua organisasi Muslim terbesar di Indonesia. 


\section{Metode Kajian}

Kajian ini merupakan penelitian pustaka yang memanfaatkan materi-materi tertulis seperti buku dan artikel jurnal untuk menganalisis fenomena keislaman yang ada di Indonesia, khususnya terkait moderatisme Islam di negara mayoritas muslim ini. Sumber literature dipilih untuk merepresentasikan gambaran peran dua organisasi, Muhammadiyah dan Nahdlatul Ulama, khususnya di Indonesia.

\section{Hasil dan Pembahasan}

Dalam sebuah kesempatan, Guru Besar Sejarah Peradaban Islam UIN Syarif Hidayatullah Jakarta, Prof. Dr. Azyumardi Azra, CBE menjelaskan bahwa wilayah peradaban Islam terbagi atas delapan cultural domain (sphere). Pertama adalah Arabic cultural domain, yang memiliki banyak tradisi dan kabilah tetapi memiliki bahasa yang sama, yaitu Bahasa Arab. Kedua adalah Iranian-Persian Islamic cultural sphere yang memiliki tradisi intelektual Persia yang sangat kuat. Ketiga adalah Turkish Islamic cultural sphere, yang menekankan tradisi ghazi (kewiraan, militerisme), tidak terlalu filosofis, hingga Turki bisa menguasai Eropa (Johnson, 1997, hal. 239 ). Keempat adalah Sudanic Islamic cultural sphere, yang memiliki orientasi tradisi lokal dan disampaikan dengan kewiraan, sehingga di Afrika Selatan banyak gerakan jihad yang bertujuan memurnikan Islam (Esposito, 1998, hal. 40). Kelima adalah Indo-Pakistan Islamic cultural sphere yang berciri khas strong mystical tradition karena banyak dipengaruhi tradisi Hindu. Keenam adalah Chino Islamic cultural sphere yang sangat menghormati leluhur. Ketujuh adalah Western Islamic cultural sphere, di mana Islam masih mengalami keterancaman sehingga Islam menjadi semacam politic of identity, dan kedelapan adalah Nusantara Islamic cultural sphere (Pengertian Nusantara), yang berciri khas Islam yang akomodatif, toleran, rilex, dan flowering (Azra, 1999, hal. 15).

Wajah Islam di beberapa wilayah ini sedikit banyak sangat dipengaruhi bagaimana metode pengintrodusian Islam, situasi perpolitikan yang tengah berlangsung, yang akhirnya membentuk identitas politik, dan sekaligus performa serta ekspresi keberagamaan Muslim di tempat tersebut. Islam di kawasan Timur Tengah, Asia Selatan dan Afrika misalnya, diintrodusir lewat media futūh (pembebasan) yang terkadang melibatkan kekuatan militer, sehingga wajah Islam yang tampak di sana terkesan rigid dan kaku. Meski futūh yang terjadi tidak selamanya berupa pemaksaan penduduk 
setempat untuk memeluk Islam, akan tetapi nampaknya wilayah-wilayah ini lebih mengalami 'Arabisasi' cukup kental. Sedangkan penyebaran Islam di Nusantara tidak melalui futūh, melainkan diperkenalkan oleh para penyebar Islam dengan cara akulturasi antara Islam dan budaya setempat yang kemudian menghasilkan kombinasi yang apik, tanpa ada yang terkalahkan, sehingga menampilkan performa Islam Nusantara yang ramah dan moderat, atau bisa disebut sebagai the least Arabicized (paling kurang mengalami'Arabisasi’) ( Azra, hal. 16).

Munculnya Gerakan Paderi di awal abad 19 di Sumatera Barat memang sempat mencatatkan wajah Islam yang garang. Gerakan yang dipelopori trio haji yaitu Haji Piobang, Haji Sumanik dan Haji Miskin yang baru pulang dari tanah Haramayn ini sangat dipengaruhi gerakan Wahabi yang saat itu sedang melanda di Arab Saudi (Steenbrink, 1984, hal. 36). Di Tanah Minang, mereka menerapkan cara radikal dalam pemberantasan praktik dan tradisi (adat) yang menurut mereka bertentangan dengan Islam, seperti tradisi judi, sabung ayam, minum arak, pakaian tak menutup aurat, dan sebagainya yang banyak dipraktikkan kelompok adat, juga sistem matriarchat yang dianut masyarakat Minang. Untungnya, gerakan Paderi ini tidak sempat melebarkan pengaruhnya ke luar daerah Minang, dan hanya berlangsung sesaat saja. Segera setelah kolonial Belanda menancapkan kakinya di Sumatera Barat, kelompok Paderi dan kaum adat bahkan bersatu untuk menghalau Belanda, seraya menghasilkan kesepakatan yang hingga kini tetap mereka pegang teguh, yaitu adat basandi syara', syara’ basandi kitabullah.

Munculnya Muhammadiyah pada tahun 1912, juga sempat menimbulkan sedikit kegaduhan di tengah masyarakat Jawa, khususnya Yogyakarta ketika itu. Masyarakat Jawa yang sangat kental dengan budaya klenik terusik dengan gerakan purifikasi yang dicanangkan gerakan yang didirikan KH Ahmad Dahlan ini. Ahmad Dahlan, yang pemikiran dan gerakannya banyak diinspirasi oleh pemikiran Muhammad Abduh dan Rasyid Ridha, menegaskan bahwa maraknya praktik takhayul, bid'ah dan khurafat di tengah masyarakat Muslim kala itu adalah salah satu bentuk aktivitas anti tauhid yang dapat mengotori akidah Islam dan bahkan termasuk tindakan syirik. Ahmad Dahlan sempat dituduh menciptakan agama baru atas gerakan purifikasi ini.

Sikap resistensi terhadap Ahmad Dahlan dan Muhammadiyah dari sebagian masyarakat Jawa tidak hanya menyangkut gerakan purifikasi dalam tataran praktik keberagamaan saja. Dalam bidang pendidikan, sekolah-sekolah yang dirintis 
Muhammadiyah sempat mendapat cemooh dari masyarakat karena mengajarkan ilmuilmu umum semisal ilmu alam, ilmu hitung, bahasa Belanda, tulisan latin, dan sebagainya. Di tengah pemahaman yang berkembang saat itu, bahwa hanya ilmu agama yang wajib dipelajari, sedangkan ilmu umum yang kebetulan diperkenalkan di Indonesia oleh sekolahsekolah Belanda hukumnya haram karena dianggap sebagai ilmu kafir, sekolah-sekolah Muhammadiyah justru mendobrak anggapan masyarakat umum ini dengan langkahnya memodernisir diri. Ahmad Dahlan bahkan sempat dicap sebagai kyai kafir karena mengadopsi sistem pendidikan Barat ini. Tidak hanya dengan mengajarkan ilmu-ilmu umum yang dianggap sebagai ilmu kafir, tetapi juga memberlakukan sistem klasikal, proses pendidikan yang menyertakan siswa laki-laki dan perempuan di kelas yang sama.

Sebaliknya, lahirnya organisasi Nahdlatul Ulama yang cikal bakalnya berasal dari sebuah komite yang mengusulkan kepada Raja Saud di Arab Saudi untuk tidak menghancurkan situs-situs bersejarah umat Islam di Tanah Hijaz, termasuk makam Nabi Muhammad SAW dan para sahabat. Komite Hijaz inilah yang pada tanggal 31 Januari 1926 akhirnya bermetamorfose menjadi Nahdlatul Ulama (NU) yang sedari lahirnya memproklamirkan diri sebagai organisasi pelestari tradisi dan nilai-nilai luhur budaya bangsa. Jargon 'Al-Muhāfazatu 'alā al-qadìm al-shālih wa al-akhdhu bi al-jadìd al-așlaḥ' (memelihara tradisi yang baik dan mengambil hal baru yang lebih baik) sangat populer di kalangan kaum Nahdhiyin.

Ide Pribumisasi Islam yang digulirkan Gus Dur pada tahun 1980-an adalah penerjemahan dari jargon ini. Ide ini sekaligus untuk meng counter pemahaman kalangan Islam fundamentalis yang dipandang ingin melakukan proyek Arabisasi di Indonesia dan menganggap bahwa Islam yang otentik mestilah yang berbau Arab atau Timur Tengah, khususnya yang dipraktikkan oleh generasi Salaf al-Ṣālih. Islam Indonesia mereka nilai sudah tidak murni lagi karena sudah banyak dikotori oleh adat dan hal lain yang berasal dari luar Islam.

Pribumisasi Islam ingin menegaskan bahwa Islam Indonesia yang diwarnai dengan berbagai local wisdom adalah Islam. Oleh karena itu, sebagai respons terhadap gejala ini, Gus Dur menggagas ide pribumisasi Islam yang memiliki beberapa karakteristik, yaitu pertama, Islam tidak dianggap sebagai alternatif ideologi, melainkan hanya dipandang sebagai faktor komplementer saja dalam kehidupan sosial, kultural, dan politik. Kedua, toleran dan menghargai tradisi, yaitu perlunya mempertimbangkan konteks lokal 
Indonesia ketika menerapkan ajaran Islam. Ketiga, progresif, bahwa Islam harus bisa berlapang dada untuk berdialog dengan tradisi pemikiran orang lain, termasuk dengn Barat. Keempat adalah membebaskan, Islam menjadi ajaran yang dapat menjawab problem kemanusiaan secara universal tanpa melihat perbedaan etnik maupun agama ( Rahmat, 2003, hal. 22).

Di awal pendiriannya, para tokoh dua organisasi ini ( Noer, 1996). memang acap kali terlibat polemik panas perihal masalah-masalah furüiyyah. Masalah niat diucapkan ataukah tidak, qunut, tahlilan, dan sebagainya, menjadi bahan perdebatan yang tak berkesudahan. Unt ungnya, polemik ini hanyalah berhenti pada tataran diskursus saja, dan tidak berimbas pada aksi anarki. Munculnya kesadaran akan pentingnya semangat ukhuwah Islamiyah, persatuan dan kesatuan semakin tumbuh ketika mereka dihadapkan pada penjajahan dan kolonialisme, khususnya Belanda dan Jepang. Dalam forum-forum politik seperti Majelis Islam A'la Indonesia (MIAI) dan kemudian Majelis Syuro Muslimin Indonesia (Masyumi). pada masa revolusi pra kemerdekaan, para tokoh dua ormas ini bersatu mewujudkan Indonesia yang berdaulat.

Moderatisme Islam yang ditampilkan dua organisasi ini setidaknya bisa dilihat dari paham keagamaan yang dianut Muhammadiyah dan NU. Di bidang theologi, dua organisasi ini mengklaim sebagai penganut ahlussunah wal jama'ah (aswaja). Dalam kajian aliran ilmu kalam (teologi), aswaja dikenal sebagai paham yang berdiri di antara dua ekstremitas paham Muktazilah dan Khawarij, antara Qadariyah dan Jabbariyah. Kelompok Muktazilah dan Qadariyah memiliki karakteristik rasionalis-liberal, sedangkan kelompok Khawarij dan Jabbariyah mempunyai kekhasan sebagai kelompok tradisionalisliteralis. Sementara itu, dalam bidang fiqh, jika NU lebih memilih mazhab Syafi'i sebagai kiblat rujukan doktrin keagamaannya, maka Muhammadiyah lebih memilih untuk tidak memihak kepada salah satu mazhab fiqh yang ada. Sikap ini bukan berarti menunjukkan Muhammadiyah sebagai gerakan anti mazhab, tetapi sebagai penegasan untuk mendapatkan referensi yang lebih luas dan sejati, langsung dari sumbernya yaitu Alquran dan al-Sunah al-maqbülah. Keputusan untuk tidak bermazhab juga didorong oleh idealisasi generasi awal Islam sebagai generasi terbaik yang tidak terkotak-kotak oleh perbedaan-perbedaan mazhab ( Ma'arif, 1995, hal. 133 ).

Sikap tawasuth yang diperlihatkan Muhammadiyah dan NU antara lain juga nampak dalam pandangan-pandangan politiknya. Tiga prinsip yang sering dijadikan dasar 
pengambilan keputusan politik NU adalah kebijaksanaan, keluwesan, dan moderatisme. Tradisi memilih jalan damai dalam wacana politik NU umumnya melalui prinsip-prinsip yurisprudensi dan kaidah-kaidah yang menganjurkan minimalisasi risiko, pengutamaan asas manfaat, dan menghindari hal-hal yang ekstrem. Inilah yang dalam penilaian Greg Fealy lebih menggambarkan pragmatisme politik ketimbang sikap idealis (Fealy, 2004, hal. 69).

Contoh konkret dari tradisi memilih jalan damai dalam politik NU terlihat pada masa penjajahan kolonial Belanda. Martin van Bruinessen mencatat, bahwa dalam periode pemerintahan kolonial Belanda, NU mengambil sikap abstain terhadap politik (19261942). Ia menahan diri dari terlibat dalam kegiatan-kegiatan politik, dan ketika membuat pernyataan politik, ia bersikap mendukung pemerintahan Belanda. Sebagai penganut paham ahlussunah wal jama'ah, dalam Muktamar tahun 1938 di Menes, Banten, NU secara de facto menyatakan Hindia Belanda sebagai dâr al-Islâm atau negeri yang dapat diterima umat Islam. Alasannya adalah karena penduduk Muslim dapat melaksanakan syariat Islam. Dalam pandangan sunni tradisional, sebuah pemerintahan yang memperbolehkan umat Islam menjalankan kewajiban-kewajiban agamanya lebih baik dari pada fitnah (chaos) yang diakibatkan pemberontakan (Bruinessen, 2009, hal. 47).

KH Ahmad Siddiq dalam menjelaskan "Pendapat NU bahwa Indonesia ketika masih dijajah Belanda adalah dār al-Islām sebagaimana diputuskan dalam Muktamar Banjarmasin 1936" mengatakan bahwa kata dār al-Islām disini bukanlah sistem politik atau ketatanegaraan, tetapi sepenuhnya istilah keagamaan (Islam), yang lebih tepat diterjemahkan sebagai wilàyatul al-Isläm (daerah Islam), bukan negara Islam. Di wilayah Islam, semua penduduk wajib memelihara ketertiban masyarakat, mencegah perampokan dan sebagainya. Akan tetapi NU menolak ikut milisi Hindia Belanda karena menurut Islam, membantu penjajah hukumnya haram ( DZ, 2013, hal. 52).

Sementara itu, Muhammadiyah memang tidak sampai pada keputusan yang menyatakan Indonesia di bawah penjajahan Belanda sebagai negoro Islam seperti yang dilakukan NU. Dalam kaitannya dengan teologi politik, Muhammadiyah tergolong ke dalam kelompok substantivistik yang tidak terlalu bernafsu menjadikan Indonesia sebagai negara Islam, seperti yang dikehendaki beberapa kelompok umat Islam Indonesia. Sejak kelahirannya, organisasi ini menegaskan bahwa tujuan didirikannya Muhammadiyah adalah terwujudnya masyarakat Islami dan penegakkan amar ma'ruf nahi munkar. Karena 
yang dituju adalah masyarakat Islami, dalam hubungannya dengan negara, meski tokohtokoh Muhammadiyah pernah memiliki saham dalam memperjuangkan Islam sebagai dasar negara dalam BPUPKI PPKI maupun Majelis Konstituante, akan tetapi pada hakikatnya Muhammadiyah dalam Anggaran Dasarnya tidak mencantumkan istilah Negara Islam (Ad-Daulah Al-Islamiyyah) (Ma'arif, 2000, hal. 8). Watak ideologis ini dalam perkembangannya mengalami transformasi, dari perjuangan legal-formal syariat Islam menjadi penyadaran umat akan kehidupan yang dilandasi nilai-nilai Islam, sehingga terwujud masyarakat yang Islami. Hal ini bukan berarti Muhammadiyah menolak pemberlakuan syariat Islam, seperti yang disuarakan organisasi-organisasi Islam lainnya seperti Hizbut Tahrir Indonesia, Majelis Mujahdidin Indonesia, dan sebagainya. Akan tetapi dalam pandangan Muhammadiyah, pelegal-formalan Islam dalam konstitusi harus mempertimbangkan situasi dan kondisi politik umat Islam, ruang dan waktu dewasa ini. Dalam kenyataannya, Muhammadiyah justru berada di garis terdepan dalam memperjuangkan tegaknya syariat Islam, seperti yang tertuang dalam Penjelasan PP Muhammadiyah,

“...Sebagai gerakan dakwah amar ma'ruf nahi munkar yang berdasarkan Islam, tentu saja Muhammadiyah berada di garis depan untuk segala usaha penegakkan syariat Islam yang bersifat menyeluruh, karena kewajiban menjalankan syariat Islam adaah bagian yang tidak terpisahkan dari keimanan kita terhadap kebenaran Islam sebagai agama"( Jurd, 2010, hal. 321).

Meskipun dalam hal-hal tertentu Muhammadiyah lebih dekat dengan pemahaman keagamaan salafiyah, namun dalam gagasan teologi politik Muhammadiyah berbeda dengan teologi kaum salaf. Dalam pengamatan Azyumardi Azra inilah yang membedakan antara teologi politik kaum salaf dengan teologi politik Muhammadiyah. Jika para tokoh salaf seperti Sayyid Quthb dan Abu al-A'la al-Maududi menggagas khilafah dengan khalifah sebagai penguasa tertingginya, maka dua istilah ini nyaris absen dalam wacana Muhammadiyah (Azra, 2000, hal. 16).

Jika pada masa revolusi kemerdekaan para tokoh dua ormas ini sangat getol memperjuangkan Islam sebagai dasar negara, nampaknya pada masa reformasi dua ormas ini mengalami perubahan orientasi dalam masalah dasar negara. Bagi keduanya, bentuk Negara Kesatuan Republik Indonesia (NKRI) berdasarkan Pancasila sudah final dan tak perlu lagi diperdebatkan. Dua ormas ini, Muhammadiyah dan NU menolak gagasan diberlakukanya kembali Piagam Jakarta seperti yang diinginkan beberapa ormas Islam seperti Hizbut Tahrir Indonesia, Majelis Mujahidin Indonesia, dan sebagainya. Dalam 
Munas dan Muber Alim Ulama NU di Jakarta tanggal 26-28 Juli 2001 dipertegas bahwa dalam amandemen UUD 1945, dasar negara menjadi prasyarat mutlak yang tidak boleh dirubah.(Abdul Rouf, 2010, 153). Kedua organisasi ini juga giat mengembangkan wawasan keislaman yang ramah dengan menekankan pentingnya demokrasi, toleransi, pluralisme, hak asasi manusia dan keadilan sosial. Tokoh-tokoh kedua organisasi ini seperti KH. Abdurrahman Wahid dari NU dan A. Syafi'i Ma'arif dari Muhammadiyah dikenal sebagai tokoh yang sangat concern dalam mengkampanyekan wajah Islam yang damai, ramah, santun, dan tidak menakutkan.

Moderatisme Muhammadiyah dan NU juga tampak dalam pandangan dua ormas terbesar di dunia ini dalam konsep jihad dan penerapannya. Dua kelompok umat Islam memiliki perspektif yang berbeda tentang konsep dan praktik jihad. Kelompok pertama, yaitu komunitas salafi jihadis tidak sepakat dengan penggunaaan arti etimologis jihad yaitu bersungguh-sungguh atau berjuang keras dalam pelaksanaan ibadah, baik mahdah maupun ghairu mahḍah. Mereka hanya meyakini jihad secara syar'i seperti yang telah didefinisikan empat mazhab utama, yaitu jihad sebagai perang. Jihad perang tidak hanya ditujukan sebagai upaya defensif saja, melainkan bisa juga ditujukan sebagai tindakan offensif. Dengan mengambil argumentasi dari perkataan Umar bin al-Khattab, bahwa khairud difá'i al-hujūmu (sebaik-baik pertahanan adalah penyerangan), salah satu pelaku bom Bali, yaitu Imam Samudra menyerukan apa yang ia sebut sebagai defoffensif (pertahanan sekaligus penyerangan). Pengeboman terhadap dua lokasi wisata di Bali pada Oktober 2001 yang ia lakukan bersama dengan beberapa anggota komunitas salafi jihadis, yang mereka sebut sebagai operasi jihad ini, dilakukan dengan strategi defoffensif (Samudra, 2004).

Kelompok kedua adalah mainstream umat Islam seperti Muhammadiyah dan Nahdlatul Ulama, menegaskan bahwa jihad tidak mesti bermakna perang. Segala kesungguh-sungguhan dan kerja keras dalam setiap kebaikan adalah salah satu bentuk jihad. Termasuk bersungguh-sungguh memerangi kebodohan, kemiskinan, korupsi, dan bentuk kedzaliman yang lain, bisa dimaknai sebagai jihad. Jihad berbentuk perang dilakukan ketika umat Islam diserang oleh pihak musuh, sebagai tindakan defensif, bukan offensif.

Demikian juga dengan konsep dār al-harb dan dăr-al-Islām, keduanya memiliki pandangan yang berbeda. Kelompok pertama menegaskan bahwa wilayah di mana syariah 
Islam belum ditegakkan, maka ia disebut sebagai dār al-harb, meski penguasanya Muslim, yang oleh karena itu wajib ditegakkan jihad atasnya. Sementara kelompok kedua berpendapat bahwa di wilayah manapun umat Muslim bisa beribadah dengan bebas maka ia adalah dăr-al-Islām yang tak boleh diperangi. Pendapat kelompok ini sejalan dengan pandangan ulama klasik seperti Abdul Qahir al-Baghdadi dan ulama lainnya seperti yang dikutip Madjid Khaddûri yang berpendapat bahwa suatu wilayah dianggap sebagai dār-alIslām ketika umat Islam dapat melaksanakan kewajibannya dengan bebas. Pandangan ulama klasik ini menunjukkan bahwa klasifikasi wilayah masuk ke dalam där al-harb atau dār-al-Islām dapat dilihat dari jangkauan pelaksanaan hukum Islam dalam wilayah tersebut, dan bukan terletak pada penguasanya, Muslim ataukan non-Muslim. Definisi ini diterima oleh sebagian ulama Muslim selama paruh abad ke-19 dan 20, antara lain Sayyid Ahmad Khan dan beberapa sarjana dan ulama Deoband dan Nadwat al-Ulamä dari India, ketika India dikuasai Inggris. Begitu juga ulama NU yang menyebut Indonesia sebagai negoro Islam pada masa penjajahan Belanda (sebelum kemerdekaan RI tahun 1945) (Khadduri, 2006).

Rentetan peristiwa yang terjadi selama tahun 2000-an, seperti peristiwa 9/11, kemudian merembet ke Indonesia semisal tragedi Bom Bali tahun 2001 dan aksi terorisme lainnya yang dilakukan segelintir umat Islam, sedikit banyak mencoreng wajah Islam Indonesia yang selama ini dikenal ramah dan toleran. Aksi kekerasan yang dilakukan segelintir kelompok radikal fundamentalis ini pada akhirnya bahkan menyeret Indonesia ke dalam peta war on global terrorism. Oleh karena itu, umat Islam Indonesia perlu kembali memperjuangankan watak asli Islam Indonesia yang moderat.

Sebagai bentuk kepedulian dan keseriusan kolektif NU dan Muhammadiyah dalam mewujudkan Islam dan masyarakat beragama yang moderat, berkeadilan dan berkeadaban, kedua organisasi ini beserta beberapa tokoh agama dari beberapa begara ASEAN seperti Malaysia, Filipina, Kamboja dan Singapura menggagas berdirinya Center for Moderate Moslem (CMM), melalui forum Jakarta International Conference yang diselenggarakan di Jakarta, pada 13-15 Oktober 2003 yang diikuti 120 pimpinan pesantren se-Jawa dan beberapa ulama negara ASEAN. CMM lahir dari sebuah keprihatinan munculnya fenomena radikalisasi agama yang dilakukan sekelompok umat Islam, khususnya pasca tragedi 9/11 di Amerika Serikat. Oleh karena itu, berdirinya CMM bertujuan antara lain, pertama, untuk menumbuhkan dan mensosialisasikan pandangan, sikap dan missi Islam 
yang moderat, ramah dan modern dalam masyarakat serta membendung radikalisasi agama dan sosial. Kedua, mewujudkan dan menstimulus lahirnya kader-kader Islam yang berwawasan luas ke depan, progresif, inklusif, dan keberagamaan yang terbuka. Ketiga, menumbuhkembangkan risalah dakwah Islam yang ramah dan damai di kalangan masyarakat internasional ( www/google.com/cmm.cairo. ). Untuk mensosialisasikan tujuan dan program-programnya ini, CMM banyak menyelenggarakan seminar, workshop, dan membuat bulletin, jurnal, dan karya-karya lainnya. Demikian juga mengadakan pelatihan bagi kelompok-kelompok da'i yang akan dikirim ke daerah pedalaman di tanah air.

Dengan beberapa usaha dari dua ormas Islam terbesar di Indonesia ini, diharapkan Islam Indonesia mampu kembali dipandang sebagai Islam yang ramah, toleran, dan moderat. Terhadap kekhawatiran sementara kalangan yang menganggap bangkitnya radikalisme di Indonesia, Greg Fealy mencoba mematahkan anggapan ini. Dalam sebuah artikelnya yang berjudul "Islamic Radicalism in Indonesia; The Faltering Revival' Indonesianis asal Australia menepis dugaan ini. Bahkan dalam analisisnya, Fealy menegaskan bahwa radikalisme Islam di Indonesia justru mengalami kemunduran dan tidak mendapatkan respons yang berarti dari mainstream umat Islam Indonesia. Indikasinya antara lain adalah dibubarkannya Forum Komunikasi Ahlussunah wal Jama'ah (FKAWJ) Laskar Jihad (LJ) di awal tahun 2002, bubarnya penerbit Sabili yang memiliki warna radikal pada tahun 2002, dan tidak marketablenya organisasi yang ditandai dengan minimnya keanggotaan dan aktivitas organisasi. Ini menjadi bukti bahwa mainstream umat Islam Indonesia tidaklah welcome terhadap organisasi yang memiliki pemikiran dan gerakan yang radikal, dan lebih memilih bergabung dengan organisasi yang terkenal dengan kemoderatannya, semisal Muhammadiyah dan NU.

\section{Apa itu Moderatisme Islam?}

Moderat diartikan sebagai sikap atau pandangan yang selalu menghindarkan perilaku atau pengungkapan yang ekstreem, atau berkecenderungan ke arah dimensi atau jalan tengah. (KBBI, 589). Diskursus tentang moderatisme telah menjadi bahan perdebatan yang cukup hangat di kalangan cendekiawan Muslim Indonesia. Dalam analisis cendekiawan muda Muhammadiyah, A. Najib Burhani, label moderat seringkali hanya menjadi baju ketika seseorang tidak bisa menjelaskan posisi dirinya di tengah perebutan pengaruh antara kelompok garis keras Islam dan kelompok liberal Islam. 
Selanjutnya peneliti LIPI ini menegaskan bahwa bagi organisasi NU dan Muhammadiyah yang belakangan mengambil posisi moderat, sama artinya mereka menghilangkan peran mereka sebagai gerakan (movement) yang memiliki visi yang jelas. Karena menjadi moderat berarti membiarkan umat mereka terus berada dalam perebutan berbagai aliran ekstreem. Bagi Burhani, menjadi moderat adalah pasif dan terus menerus menjadi obyek. Bagi kedua organisasi ini, moderat lebih berarti medioker daripada netral. Dengan mengutip pendapat Azyumardi Azra dan Ketua Muhammadiyah, Din Syamsuddin yang menjelaskan bahwa istilah Islam moderat memiliki padanan kata dengan istilah ummatan wasatan atau al-din al-wasat, juga pendapat cendekiawan Iran Ali Syariati dan tokoh Muhammadiyah HAMKA, bahwa al-din al-wasat berarti bahwa Islam berada di tengah antara esoterisme Kristiani dan eksoterisme Yahudi, pada akhirnya, Burhani memberikan penegasan bahwa istilah al-din al-waș at seperti yang dimaksudkan dalam QS 2;143 mesti dimaknai sebagai center atau heart, yaitu agama yang menjadi pusat dan jantung peradaban (Burhani, 2008).

Berbeda dengan Najib Burhani, Guru Besar UIN Jakarta sekaligus mantan Wakil Menteri Agama RI, Nasaruddin Umar, menegaskan bahwa Islam moderat tidak identik dengan Islam liberal yang menolerir segala segi kehidupan modern dan pro terhadap jargon-jargon sekuler. Juga bukan setengah Muslim yang sinkretis, ataupun mereka yang fobia terhadap Islam. Menurutnya, sikap moderat juga tidak bisa diukur dari segi penampilan saja, seperti tidak berjenggot, berjubah, dan atribut ketimuran lainnya. Akan tetapi, moderasi lebih banyak ditentukan oleh pikiran dan sikap seseorang terhadap agamanya. Dalam pandangan Nasaruddin, jika pemahaman seseorang terhadap ajaran Islam mendalam dan holistik, maka dengan sendirinya mereka akan bersikap moderat. Karena sesuai dengan namanya, Islam secara harfiah berarti moderat, jalan tengah, tunduk dengan kritis, dan pasrah dengan nilai-nilai ajaran Islam. Islam tidak disebut salam yang cukup hanya memelihara nilai-nilai luhur (values) saja, tetapi juga berisi norma ajaran. Islam juga tidak disebut istislām (bentuk khumasi) yang mengisyaratkan kesempurnaan ketaatan, karena bagaimanapun manusia tetaplah manusia, bukan malaikat yang bebas dari kekhilafan. Islam adalah Islām (bentuk ruba'î) yang menegaskan kejalantengahan (moderate system), yang sesuai dengan penegasan Rasul, bahwa khairul umūri awsat uhā, sebaik-baik perkara adalah menempuh jalan tengah ( Umar, 2013).

Di antara ciri utama Islam moderat antara lain, pertama, menerima demokrasi. 
Beberapa aktivis Islam membuang kata 'Barat', sedangkan yang lain menerima sebagian yang sesuai dengan prinsip-prinsip Islam. Prinsip shûrâ dipandang sebagai sinonim bagi demokrasi. Ciri kedua adalah dengan meyakini demokrasi sama artinya dengan menolak gagasan negara Islam yang dikendalikan para ulama. Oleh karena itu, para aktivis Islam moderat percaya bahwa tidak ada seorangpun yang memiliki hak bicara mewakili Allah. Ketiga, salah satu perbedaan utama antara Islam radikal dan moderat adalah sikap terkait masalah penerapan syariah. Bagi Islam moderat, tafsir tradisional terhadap syariah tidak sesuai dengan prinsip demokrasi dan tidak menghormati prinsip HAM. Keempat, menghormati hak-hak perempuan dan agama minoritas, dan ciri kelima adalah menolak terorisme dan kekerasan illegal (Hizbut Tahrir Indonesia).

Karakteristik yang melekat dalam Islam Moderat inilah yang oleh Fazlurrahman disebut sebagai Islam Neo-modernis. Islam Neo-modernis berusaha berada di tengah dan menjembatani gap yang ada di antara kaum tradisionalis yang menolak modernitas dengan kaum modernis yang menelan mentah-mentah modernisme Barat. Gerakan neomodernisme memperjuangkan bagaimana agar kaum Muslim mampu menghadapi tantangan dan peradaban modern dengan tetap berpijak pada khazanah Islam otentik. Sehingga Islam tetap “ṣălị̣ li kulli zamān wa makān”(Pribadi \& Haryono, 2002, hal. 211). Bagi Rahman, neo-modernisme inilah prasyarat bagi kemajuan Islam saat ini.

Moderatisme kemudian biasanya dihadapkan secara diametral dengan sikap radikalfundamentalis. Dawisha, seperti dikutip Azyumardi Azra mendefinisikan radikalisme sebagai sikap jiwa yang membawa kepada tindakan-tindakan yang bertujuan melemahkan dan mengubah tatanan politik mapan dan biasanya dengan cara kekerasan, serta menggantinya dengan sistem baru (Azra, hal. 109). Beberapa prinsip yang melekat dalam gerakan fundamentalisme Islam seperti yang dikemukakan Azyumardi Azra. Pertama, prinsip oppositionalism (paham perlawanan), terhadap segala sesuatu yang dipandang membahayakan eksistensi agama, baik berupa modernisme, sekulerisme, maupun tata nilai Barat secara umum. Kedua, penolakan terhadap hermeneutika. Ketiga, penolakan terhadap pluralisme dan relativisme, dan keempat penolakan terhadap perkembangan historis dan sosiologis. Artinya, perkembangan masyarakat harus menyesuaikan diri dengan kitab suci, bukan sebaliknya.

Meski dikenal sebagai ormas yang mengusung watak moderatismenya, dalam amatan cendekiawan Muslim Indonesia, Azyumardi Azra, Muhammadiyah dan NU 
pernah melakukan aksi yang bisa dikatakan radikal, meski dalam tataran diskursus. Mengutip pendapat Mitsuo Nakamura, Indonesianis emeritus asal Jepang, Azyumardi Azra mencatat radikalisme yang pernah diperlihatkan Nahdlatul Ulama, yaitu pada era Orde Baru ketika NU pada masa kepemimpinan Abdurrahman Wahid memutuskan untuk kembali ke khittah 1926 dan menerima asas tunggal Pancasila. Radikalisme NU juga terlihat ketika secara mati-matian membela status quo kekuasaan Presiden Gus Dur dengan mengangkat konsep bughat dan jihad. Azra pada akhirnya berkesimpulan bahwa radikalisme NU cenderung sangat politis, dan tidak lebih dari political opportunism, dengan menggunakan dalil dan hujjah yang terdapat dalam fiqih siyasah klasik. Akan tetapi, perkembangan terakhir menunjukkan betapa di kalangan Nahdhiyin telah muncul pemikir-pemikir liberal, seperti Gus Dur sendiri, Said Agil Siradj, Masdar F. Mas'udi, Ulil Abshar Abdalla, dan sebagainya.

Selanjutnya, Azra juga menilai bahwa di tingkat pemahaman keagamaan, Muhammadiyah pada dasarnya bersifat radikal, karena ia bertujuan melakukan perubahan menyeluruh terhadap berbagai bentuk kepercayaan dan praktek keislaman yang sudah tercampur dengan bid'ah, khurafat dan takhayul. Hanya saja, dalam mengaktualisasikan radikalisme ideologinya ini, Muhammadiyah menggunakan cara dan pendekatan yang persuasive melalui usaha pendidikan, kesehatan, sosial, dan sebagainya. Sebaliknya, liberalisasi pemikiran dan praksis Muhammadiyah terlihat ketika ia menyerukan penolakan terhadap taklid kepada ulama dan membuka pintu ijtihad. Muhammadiyah juga sangat responsif dan mengadopsi berbagai bentuk sistem dan lembaga modern.

\section{Penutup}

Dalam pandangan Penulis, Idealnya, Islam moderat lebih menegaskan karakteristik gerakannya. Identitas Islam ditegaskan dengan tanpa ragu-ragu, bahwa Islam adalah ajaran revolusioner yang telah mampu mengubah kejahiliyahan menjadi sebuah kebudayaan dan peradaban luhur adalah kenyataan sejarah yang tidak bisa dipungkiri. Akan tetapi, kesuksesan Islam mengubah peradaban dunia dan masih tetap lestari eksistensinya sebagai sebuah institusi dan keyakinan milyaran umat manusia adalah karena kelenturan dan daya adaptif ajaran-ajarannya. Karena jika Islam bersikap rigid dan kaku terhadap segala perkembangan dan dinamika zaman, tentu telah menjadi usang dan ditinggalkan para penganutnya. Karena itu, gerakan sosial Islam moderat seperti Muhammadiyah dan NU, haruslah tetap menjaga ciri khas keislamannya yang 
sejati tanpa perlu memperjuangkannya dengan cara-cara kekerasan. Karena bagaimanapun, gerakan Islam tetap harus memperlihatkan missi Islam sebenarnya sebagai gerakan yang mengusung missi rahmatan li al 'ālamīn.

\section{Daftar Pustaka}

DZ, A. M. (2013). Piagam Perjuangan Kebangsaan. Jakarta: PBNU.

Jurd, S. (2010). Muhammadiyah dalam Dinamika Politik Indonesia 1966-2006. Yogyakarta: Pustaka Pelajar.

Noer, D. (1996). Gerakan Modern Islam di Indonesia 1900-1942. Jakarta : LP3ES.

Rahmat, M. I. (2003). Islam Pribumi, Islam Indonesia. Jakarta: Erlangga.

Umar, N. (2013, April 5). Islam Moderat. Jurnalnasional.com.

Azra, A. (1999). Renaisans Islam Asia Tenggara; Sejarah Wacana dan Kekuasaan. Bandung: Remaja Rosdakarya.

Azra, A. (2000). Tinjauan Teologis-Historis, dalam Rekonstruksi Gerakan Muhammadiyah pada Era Multiperadaban. Yogyakarta: UII Press.

Bruinessen, M. V. (2009). NU; Tradisi Relasi -Relasi Kuasa, Pencarian Wacana Baru. Yogyakarta: LkiS.

Burhani , A. N. (2008, Februari). Islam Moderat Adalah Sebuah Paradoks, dalam Muhammadiyah Studies. Jurnal Ma'arif, Vol. 3, No. I.

Esposito, J. L. (1998). Islam and Politics. New York: Syracuse University.

Fealy, G. (2004). Islamic Radicalism in Indonesia; the Faltering Revival. (Institute of Southeast Asian Studies). http://www.jstor.org/stable/27913255.

Hizbut Tahrir Indonesia. (t.thn.). Gerakan Islam Moderat. http://hizbut-tahrir.or.id.

Johnson, J. T. (1997). The Holy War Idea in Western and Islamic Tradition (terjemahan). Yogyakarta: Qalam.

Khadduri, M. (2006). War and Peace in The Law of Islam. New jersey: The John Hopkins University Press.

Ma'arif, A. S. (2000). Tinjauan Teologis, dalam Rekonstruksi Gerakan Muhammadiyah pada Era Multiperadaban. Yogyakarta: UII Press.

Ma'arif, A. S. (1995).

http://id.facebook.Dunia Pengetahuan. 
Pribadi , A., \& Haryono, M. Y. (2002). , Post Islam Liberal. Jakarta: Gugus Press.

Samudra, I. (2004). Aku Melawan Teroris. Solo: Jazeera.

Steenbrink, K. (1984). Beberapa Aspek Tentang Islam di Indonesia Abad ke-19. Jakarta: Bulan Bintang.

www/google.com/cmm.cairo. 
